\title{
Grafting for Sustainable Growth Performance of Melon (Cucumis melo) Under Salt Stressed Hydroponic Condition
}

\author{
Firdes Ulas $^{1 *}$, Alim Aydın ${ }^{1}$, Abdullah Ulas ${ }^{2}$ and Halit Yetisir ${ }^{1}$
}

\begin{abstract}
The aim of the present study was to find out whether grafting could improve salinity tolerance of melon plants, and whether possible induction of tolerance to salinity was linked with the defense of the photosynthetic apparatus. The climate chamber experiment was carried out to determine main stem length, leaf chlorophyll index (SPAD), fresh weight of shoot and root, and root length. Under climate chamber conditions, two melon cultivars [galia type Citirex F1) and standard type (Kirkagac Manisa Altinbas)] were grafted onto two different commercial Cucurbita maxima x C. moschata hybrid rootstocks (Kardosa and Nun 9075) and grown in $8 \mathrm{~L}$ pots filled continuously with aerated nutrient solution under two different salt levels $(1$ and $8 \mathrm{dS} / \mathrm{m})$ with three replications. The results indicated that grafted and un-grafted plants were significantly $(\mathrm{P}<0.001)$ affected by different salt levels. Grafted plants had better growth performance than un-grafted plants under both control and saline conditions. The SPAD value of the un-grafted plants significantly decreased as salinity stress increased, while root fresh weight of the grafted plants significantly increased under salinity stress. Under saline conditions the highest shoot fresh weight, and SPAD value were recorded in graft combination Nun 9075/ Citirex. These results suggest that the use of salt tolerant Cucurbita maxima $\mathrm{x}$ C. moschata hybrid rootstocks can improve crop performance in melon under salt stress, whereas the appropriate scion/ rootstock combinations under saline conditions will be investigated for fruit yield and quality parameters in further studies.
\end{abstract}

Keywords: Commercial rootstock, salinity tolerance, nutrient solution, grafting, melon

\section{Introduction}

Melon (Cucumis melo L.), belonging to the Cucurbitaceae family, is an important horticultural crop, which is often cultivated in arid and semi-arid regions of the world, where salinity threats is to be, or already is, a serious problem [1], despite the advanced management techniques developed in recent decades [2]. Melon production was estimated to be 29.6 million tons in 2014 for a cultured area of 1.178,808 ha [3], the main producing countries being China (14.7 million tons) followed by Turkey $(1.7$ million tons), Iran (1.4 million tons), and Egypt (1.04 million tons). Melon is known to be moderately tolerant to salinity and salinity is a major environmental restriction limiting melon production worldwide. In the world's arable land up to $20 \%$, and in all irrigated lands up to $50 \%$, are adversely affected by salinity [4]. Saline irrigation water, low-level rainfall, high-level evaporation, excessive irrigation without proper drainage in inlands and underlying rocks rich in harmful salts can cause salinity problems in agricultural areas

\footnotetext{
${ }^{1}$ Erciyes University, Agricultural Faculty, Horticulture Dept., Kayseri, Turkey

${ }^{2}$ Erciyes University, Agricultural Faculty, Soil Sci. and Plant Nutrition Dept., Kayseri, Turkey.

*Corresponding Author.
} 
[5]. When crops are grown under saline conditions, a majority of crop plants are not able to survive; or are able to survive only with limited growth and yield [6, 7]. Saline irrigation causes several types of damage such as growth inhibition $[8,9]$, metabolic disturbances [10], and yield and quality losses [11]. In melon production, salt stress decreases biomass of the shoot and fruit production, and these changes are accompanied by enhanced $\mathrm{Na}^{+}$and $\mathrm{Cl}^{-}$concentrations and a decreased $\mathrm{K}^{+}$concentration [12]. If a solution to problems that are caused by salt stress can be proposed, it will have a positive effect on crop yield and production. One possible way to reduce the detrimental effects of salt stress on high-yielding cultivars might be to graft them onto saline-tolerant rootstocks with the capability of inducing salt tolerance to the scion [13]. Grafting is known as the union of two or more properly selected pieces of living plant tissues or fractions that grow as a single plant.

A first grafted vegetable was performed in Korea and Japan in the late 1920s by grafting watermelon onto gourd rootstocks $[13,14]$. It is an innovative technique for the suitable cultivation of fruit-bearing vegetables (tomatoes, bean, eggplant, cucumber, melon, and watermelon) in Japan, Korea, the Mediterranean basin, and several European countries [15], where land use is very intensive and continuous cropping is a common practice [16]. Grafting has contributed to sustainable agriculture by reducing the amount of chemicals used to disinfect the soil, as it has been used to confer tolerance to pests and diseases of the root system [17, 18, 19, 20], to improve fruit quality [21], to increase the absorption of nutrients and the mineral content in the aerial portion of the plant [22], to confer tolerance to high and low temperatures [23, 24], drought, salt, flooding, etc. $[25,26,27,28]$, and to improve plant vigour and the post-harvest lifetime of the fruits [29]. Up to now the effects of grafting on melon plants were carried out by many authors to achieve improved results such as resistance to pests and diseases in soil and the tolerance to low temperatures; increased plant growth, total and early yield and extending the plant's economic life by uptaking water and nutrients [30, 31, 32, 33, 34, 35, 36, 37]. Nevertheless, more comprehensive studies on the melon plants have to be conducted to better understand whether grafting could improve salinity tolerance and determine whether possible induction of tolerance to salinity was linked with the defense of the photosynthetic apparatus.

\section{Materials and Methods}

\subsection{Plant material, treatments and experimental design}

An experiment was conducted under climate chamber conditions at the Faculty of Agriculture, Erciyes University, Kayseri- Turkey. For the vegetation period, the average day/night temperatures was $25 / 22{ }^{\circ} \mathrm{C}$, the relative humidity was $60-80 \%$ and a photoperiod of $16 \mathrm{~h}$ of light. Two melon cultivars [galia type (Citirex F1) and standard type (Kırkağaç Manisa Altinbas)] were used as scion and two different commercial Cucurbita maxima x C. moschata hybrid rootstocks (Kardosa and Nun 9075) were used as rootstock materials. The seeds were sown in multipots filled with mixture of peat ( $\mathrm{pH}$ : 6.0-6.5) and perlite $(2 \mathrm{v}: 1 \mathrm{v})$. When the seedlings developed five or six true leaves, scions were grafted onto rootstocks. The un-grafted scion varieties were used as control plants. After grafting, plants were healed and acclimatized in the tunnel covered with doublelayered plastic film and shade cloth in the climate chamber for one week [38]. In order to 
prevent grafted plants from wilting by the excessive transpiration and to enhance healing, the tunnel was closed for the first three or four days of healing and acclimatization period. For the next three or four days, the opening and closing of the tunnel were done depending on the conditions of grafted plants and growth room. This was done for the acclimatization of grafted plants to environmental conditions outside tunnel. After the end of healing and acclimatization, grafted plants were transplanted to plastic pots after roots were washed from growth media. The experiment was conducted with two different salt levels $(1 \mathrm{dS} / \mathrm{m}$ and $8 \mathrm{dS} / \mathrm{m})$. Each pot was filled with $8 \mathrm{~L}$ cultivation solution that was aerated by an air pump. The nutrient solution contained $1.5 \mathrm{mM}$ calcium nitrate $\left(\mathrm{Ca}\left(\mathrm{NO}_{3}\right)_{2},\right) 250 \mu \mathrm{M}$ monopotassium phosphate $\left(\mathrm{KH}_{2} \mathrm{PO}_{4}\right), 500 \mu \mathrm{M}$ potassium sulfate $\left(\mathrm{K}_{2} \mathrm{SO}_{4}\right), 325 \mu \mathrm{M}$ magnesium sulfate $\left(\mathrm{MgSO}_{4} .7 \mathrm{H}_{2} \mathrm{O}\right), 50 \mu \mathrm{M}$ sodium chloride $(\mathrm{NaCl})$. Micronutrients were $80 \mu \mathrm{M}$ iron (Fe) (III)- ethylenediaminetetraacetic acid (EDTA)- sodium (Na), $0.4 \mu \mathrm{M}$ manganese sulfate $\left(\mathrm{MnSO}_{4}\right), 0.4 \mu \mathrm{M}$ zinc sulfate $(\mathrm{ZnSO} 4), 0.4 \mu \mathrm{M}$ copper sulfate $\left(\mathrm{CuSO}_{4}\right), 8 \mu \mathrm{M}$ boric acid $\left(\mathrm{H}_{3} \mathrm{BO}_{3}\right), 0.4 \mu \mathrm{M}$ sodium molybdate $\left(\mathrm{Na}_{2} \mathrm{MoO}_{4}\right)$. Solutions were changed completely every week in the first two weeks. The experiment was in a completely randomized block design with three replications and six plants in each replication. The experiment was terminated at the end of 35 days.

\subsection{Shoot- root fresh weight and root length measurements}

At the end of the experiment plants were harvested by separating them into shoot and roots. Main stem length $(\mathrm{cm})$ was measured by using a ruler. For the fresh weight determination plant organs were fractioned into the leaf, stem and roots and then weighed. Each fully developed leaf was counted and recorded as leaf numbers $(\mathrm{LN}) /$ plant. The root length of the grafted and un-grafted plants were measured by using the special software program WinRHIZO (Win/Mac RHIZO Pro V. 2002c Regent Instruments Inc. Canada) after recording the root fresh weight.

\subsection{Leaf chlorophyll content (SPAD) measurements}

For each experimental treatment, SPAD readings were taken with the Minolta SPAD-502 chlorophyll meter. During the growth period, two series of SPAD 502 chlorophyll meter readings were obtained at the centre of the leaves on the fully expanded youngest leaf for each treatment.

\subsection{Statistical Analysis}

Analysis of variance (ANOVA) was performed using the SAS program (SAS Institute, Cary NC, USA). If ANOVA determined that the effects of the treatments were significant $(\mathrm{P}<0.05$ for $\mathrm{F}$-test), then the treatment means were separated by Duncan's Multiple Range Test.

\section{Results and Discussion}

\subsection{The leaf number and leaf chlorophyll index (SPAD)}

At the end of the experiment generally plant growth was affected by increasing the salt level of the nutrient solutions. Because the $\mathrm{NaCl}$ concentration in the nutrient 
solution was increased, plant growth significantly decreased. Growth performance of the plants was dependent on genotype and salinity. The results of the leaf number and leaf chlorophyll determined as SPAD readings at the end of the growing cycle of graft combination and control plants in different salt levels $(1 \mathrm{dS} / \mathrm{m}$ and $8 \mathrm{dS} / \mathrm{m})$ are shown in Table 1. Leaf number and leaf chlorophyll content were significantly $(\mathrm{P}<0.01)$ affected by grafting, different salt levels and grafting $\mathrm{x}$ salt interaction. Under control conditions, the graft combination of Kardosa/ Citirex has significantly higher leaf number, whereas the un-grafted plant of Altinbas has the minimum leaf number. On the other hand, the graft combination of Nun 9075/ Citirex has significantly higher leaf number as compare to the un-grafted plants under salt conditions. Compared to the unstressed plants, $8 \mathrm{dS} / \mathrm{m} \mathrm{NaCl}$ decreased the leaf number of the Altinbas and Kardosa/ Citirex plants by 34.3 and $60.5 \%$, respectively. Under salt stress conditions decline in number of leaves has been studied previously on grafted watermelon plants. Crimson Tide F1 watermelon variety was grafted on to some bottle gourd (Lagenaria siceraria) genotypes (Commercial rootstocks: Argentario and RS841; Bottle gourd genotypes: 7007 and 35-02) and tested under two different saline conditions (1 and $6 \mathrm{dS} / \mathrm{m}$ ). The graft combinations of Crimson tide/70-07 and Crimson tide/35-02 had significantly higher leaf number than un-grafted watermelon plants of Crimson tide under saline conditions [39]. Moreover, another study reported that using different rootstock genotypes had significantly positive effects on the total chlorophyll quantity and thus on the photosynthesis metabolism of grafted tomato plants grown under saline conditions [40].

Regarding leaf chlorophyll index, under control conditions the graft combination of Kardosa/Altinbas has significantly higher SPAD values, while the ungrafted plants of Citirex has significantly lower SPAD values. On the contrary, under salt condition significantly higher SPAD value was produced when Kardosa and Nun 9075 were used as a rootstock as compared to the un-grafted plants of Altinbas and Citirex. Under saline conditions, in many plants species growth inhibition is often linked with a reduction in their photosynthetic capacity [41, 42, 43, 44]. As the $\mathrm{NaCI}$ concentration increased, net photosynthesis level decreased in watermelon plants [45]. Leaf chlorophyll content decreased under saline conditions in melon [46], tomato [47] and Turkish tobacco varieties (Nicotiana tabacum) [48]. Under saline conditions, photosynthesis rate increased in grafted cucumber plants compared to the rate in non-grafted plants [49]. The study of [50] suggested that the grafted melons were more tolerant to salinity than non-grafted ones; they suggested that grafted plants developed various mechanisms to avoid the physiological damage caused by excessive accumulation of $\mathrm{Cl}^{-}$and $\mathrm{Na}^{+}$in the leaves, including exclusion of $\mathrm{Cl}^{-}$and/or reduction of $\mathrm{Cl}^{-}$absorption by the roots, and the replacement or substitution of total $\mathrm{K}^{+}$by total $\mathrm{Na}^{+}$in the foliage.

Table 1. The effects of graft combination and different salt levels $(1 \mathrm{dS} / \mathrm{m}$ and $8 \mathrm{dS} / \mathrm{m})$ on leaf number and leaf chlorophyll index of melon plants. Values denoted by different letters (upper and lower case letters for control and salt treatment, respectively) are significantly different between genotypes within columns at $\mathrm{P}<0.05$. ns, non-significant. $* \mathrm{P}<0.05$, $* * \mathrm{P}<0.01$ and $* * * \mathrm{P}<$ 0.001 .

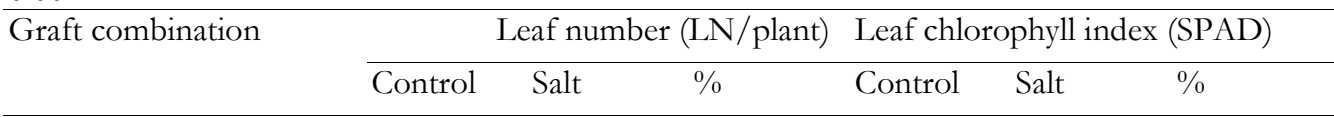




\begin{tabular}{|c|c|c|c|c|c|c|}
\hline & & & Reduction & & & Reduction \\
\hline Altinbas & $25.6 \mathrm{D}$ & $16.8 \mathrm{c}$ & 34.3 & $38.83 \mathrm{C}$ & $33.72 \mathrm{~b}$ & 13.2 \\
\hline Citirex & $30.9 \mathrm{C}$ & $12.9 \mathrm{~d}$ & 58.1 & $36.65 \mathrm{D}$ & $33.46 \mathrm{~b}$ & 8.7 \\
\hline Nun 9075/ Citirex & $45.9 \mathrm{~B}$ & $27.4 \mathrm{a}$ & 40.2 & $41.02 \mathrm{AB}$ & $40.78 \mathrm{a}$ & 0.6 \\
\hline Nun 9075/ Altinbas & $46.2 \mathrm{~B}$ & $22.4 \mathrm{~b}$ & 51.4 & $40.53 \mathrm{BC}$ & $38.59 \mathrm{a}$ & 4.8 \\
\hline Kardosa/ Citirex & $48.3 \mathrm{~A}$ & $19.1 \mathrm{~b}$ & 60.5 & $39.22 \mathrm{C}$ & $38.33 \mathrm{a}$ & 2.3 \\
\hline Kardosa/ Altinbas & $47.4 \mathrm{~B}$ & $20.2 \mathrm{~b}$ & 57.4 & $42.0 \mathrm{~A}$ & $37.08 \mathrm{a}$ & 11.7 \\
\hline F Test & $\begin{array}{l}\text { Genotype } \\
* * *\end{array}$ & $\begin{array}{l}\text { Salt } \\
* * *\end{array}$ & $\begin{array}{l}\text { Gen.xSalt } \\
* * *\end{array}$ & $\begin{array}{l}\text { Genotype } \\
* * *\end{array}$ & $\begin{array}{l}\text { Salt } \\
* * *\end{array}$ & $\begin{array}{l}\text { Gen.xSalt } \\
* * *\end{array}$ \\
\hline
\end{tabular}

\subsection{Biomass production and partitioning}

Results of shoot and root fresh weight of the grafted and un-grafted plants grown in different salt levels $(1 \mathrm{dS} / \mathrm{m}$ and $8 \mathrm{dS} / \mathrm{m})$ at the end of the growing cycle are shown in Table 2 . Fresh weight of shoot and root were significantly affected $(\mathrm{P}<0.01)$ by grafting, different salt levels and grafting $\mathrm{x}$ salt interaction. Fresh matter of the shoot decreased by different rates in each genotype with salt application. The grafted plants had significantly higher shoot fresh weight as compared to un-grafted plants under both control and saline conditions. Under control conditions, the graft combinations of Nun 9075/Citirex had significantly higher shoot fresh matter, though the un-grafted plants of Altinbas had lower shoot fresh matter. In grafted and un-grafted melon plants shoot fresh matter decreased in response to an increase of salinity in the nutrient solution. Conversely, the graft combination of Nun 9075/Citirex had significantly higher shoot fresh matter as compared to the un-grafted plants under salt stress conditions. On the other hand, the un-grafted plants of Citirex and Altinbas had lower shoot fresh matter under saline conditions. As compared to the unstressed plants, salinity decreased the shoot fresh matter of Kardosa/ Altinbas and Citirex plants by 28.8 and $68.5 \%$, respectively. Likewise, in a study by [51], as the $\mathrm{NaCl}$ concentration increased, reduction in shoot and leaf dry matter was observed. The shoot growth inhibitions are related with a decline in number of leaves, fresh and dry biomass accumulation, and shoot elongation [52, 53, 54]. Under saline conditions, shoot dry matter and leaf area decreased progressively in cucumber plants. Though, plants grafted onto salt-tolerant pumpkin rootstock of Figleaf Gourd (Cucurbita ficifolia Bouche) and especially the ones grafted onto salt-tolerant pumpkin rootstock of Chaojiquanwang (Cucurbita moschata Duch) showed smaller reductions compared to the self-grafted cucumber plants [55]. In another study, shoot dry matter was significantly higher in grafted melon plants than un-grafted melon plants under salt stress conditions [56].

Concerning the root fresh weight, the results in our study show that grafted and un-grafted melon plants varied differentially in response to the salinity of their root environments. Under both control and salt stress conditions the un-grafted plants of Altinbas had significantly higher root fresh matter than all graft combinations. The reason might be that the high salinity stress, which has restricted mineral nutrients in the root zone, induces expanded root growth to produce more root surface. Calcium (Ca) plays an important role in processes that preserve the structural and functional integrity 
of the plant membrane, stabilizes cell wall structures, regulates ion transport and selectivity, and controls ion exchange behavior as well as cell wall enzymes [57]. To provide more $\mathrm{Ca}$ elements in plant tissues, the more root mass was occurred in grafted plants that is formed by un-grafted plants. These findings are contrary to those of [39] who found that the grafted watermelon plants have significantly higher root fresh mass than un-grafted watermelon plants under salt stress conditions. The differences between our and Yamac's (2017) studies could be the results of using different types of graft materials (e.g. Lagenaria) as the rootstocks.

The reduction in the root fresh mass was ranked between -70.2 and $65.5 \%$. The minimum reduction was observed in the graft combination of Kardosa/ Citirex (-70.2 $\%$, while the maximum reduction was observed in Citirex $(65.5 \%)$. Decline in plant shoot and root fresh- dry weights in response to salt stress has been reported for other crops, such as melon [58], cucumber [59], strawberry [60], tomato [61], eggplant [62], pepper [63], and broad bean [51]. Up to now in many published studies it was reported that, because of the strong and intense root structure of the grafted plants, the improved crop growth and performance of grafted plants was dependant on the increment of root hairs, and root length; thus they acquire more water and mineral elements from the soil and send them to aerial parts of the plant $[64,65,66,67,68,69,30]$.

Table 2. The effects of graft combination and different salt levels $(1 \mathrm{dS} / \mathrm{m}$ and $8 \mathrm{dS} / \mathrm{m})$ on shoot and root fresh weight of melon plants. Values denoted by different letters (upper and lower case letters for control and salt treatment, respectively) are significantly different between genotypes within columns at $\mathrm{P}<0.05$. ns, non-significant. $* \mathrm{P}<0.05, * * \mathrm{P}<0.01$ and $* * * \mathrm{P}<0.001$.

\begin{tabular}{lllllll}
\hline & \multicolumn{3}{c}{$\begin{array}{c}\text { Shoot fresh weight } \\
\text { (g/plant) }\end{array}$} & \multicolumn{3}{c}{$\begin{array}{c}\text { Root fresh weight } \\
\text { (g/plant })\end{array}$} \\
\cline { 2 - 7 } Graft combination & Control & Salt & Reduction & Control & Salt & $\begin{array}{c}\% \\
\text { Reduction }\end{array}$ \\
\hline Altinbas & $198.8 \mathrm{~F}$ & $80.0 \mathrm{~d}$ & 59.8 & $123.9 \mathrm{~A}$ & $72.4 \mathrm{a}$ & 41.6 \\
Citirex & $241.5 \mathrm{E}$ & $76.0 \mathrm{~d}$ & 68.5 & $72.4 \mathrm{~B}$ & $25.5 \mathrm{c}$ & 65.5 \\
Nun 9075/ Citirex & $357.6 \mathrm{~A}$ & $225.5 \mathrm{a}$ & 37.0 & $30.8 \mathrm{E}$ & $52.5 \mathrm{~b}$ & -70.2 \\
Nun 9075/ Altinbas & $301.0 \mathrm{C}$ & $185.6 \mathrm{c}$ & 38.3 & $43.1 \mathrm{D}$ & $53.7 \mathrm{~b}$ & -24.7 \\
Kardosa/ Citirex & $332.3 \mathrm{~B}$ & $212.1 \mathrm{~b}$ & 36.2 & $32.2 \mathrm{E}$ & $52.8 \mathrm{~b}$ & -64.0 \\
Kardosa/ Altinbas & $271.0 \mathrm{D}$ & $192.8 \mathrm{c}$ & 28.8 & $50.9 \mathrm{C}$ & $56.2 \mathrm{~b}$ & -10.3 \\
\hline \multicolumn{1}{c}{ F Test } & Genotype & Salt & Gen.xSalt & Genotype & Salt & Gen.xSalt \\
& $* * *$ & $* * *$ & $* * *$ & $* * *$ & $* * *$ & $* * *$ \\
\hline
\end{tabular}

The results of the main stem length and root length at the end of the growing cycle are shown in Table 3. The main stem length and root length of the grafted and ungrafted melon plants at the end of the growing cycle varied under different salt levels. The grafted and un-grafted plants grown in the hydroponic, salt conditions were noticeably smaller and less vigorous than the plants grown in the non-saline conditions. Main stem length was significantly $(\mathrm{P}<0.01)$ affected by grafting, different salt levels and grafting $\mathrm{x}$ salt interaction. The grafted plants had significantly longer stem length as 
compared to un-grafted plants under saline conditions. Under control conditions, the longest plant main stem length was measured in Altinbas, while the shortest was measured in Nun 9075/ Citirex and the control plant of Citirex. Salinity decreased the main stem length of Kardosa/ Altinbas and Citirex plants by 31.3 and 57.9 \%, respectively. Conversely, the graft combination of Kardosa/ Altinbas has significantly longer stem length as compared to the un-grafted plants of Citirex under salt conditions. As the salinity level increased, plant main stem length decreased [70]. It has been reported that salinity causes reduction at stem length parameter in okra plants [71]. In our study, similar results were also detected (Table 3). Our results are in line with those of [39] who reported that the grafted watermelon plants have significantly longer stem lengths than un-grafted watermelon plants under salt stress conditions.

Regarding the root length, root length was significantly affected $(\mathrm{P}<0.01)$ by grafting and grafting $\mathrm{x}$ salt interaction, but not in different salt levels. Under control conditions the graft combination of Nun 9075/ Citirex has significantly higher root length; while the un-grafted plant of Altinbas produced lower root length. Under saline conditions, the graft combination of Kardosa/ Citirex has significantly higher root length; while the un-grafted plant of Citirex produced lower root length. Salinity causes a decline in root length between $-44.6 \%$ and $24.7 \%$ depending on the rootstocks. The root length was ranked between $28.3 \mathrm{~m} /$ plant and $69.8 \mathrm{~m} /$ plant under salinity. The graft combination of Kardosa/Citirex $(69.8 \mathrm{~m} /$ plant) has significantly higher root length, while the un-grafted plant Citirex $(28.3 \mathrm{~m} /$ plant $)$ produced lower root length. Salt stress reduces transpiration and respiration as well as water uptake and root development [72]. Likewise in our study, [39] observed that salt stress caused a reduction in root length depending on genotypes as compare to control plants in watermelon plants.

Table 3. The effects of graft combination and different salt levels $(1 \mathrm{dS} / \mathrm{m}$ and $8 \mathrm{dS} / \mathrm{m})$ on main stem length and root length of melon plants. Values denoted by different letters (upper and lower case letters for control and salt treatment, respectively) are significantly different between genotypes within columns at $\mathrm{P}<0.05$. ns, non-significant. $* \mathrm{P}<0.05,{ }^{*} \mathrm{P}<0.01$ and $* * * \mathrm{P}<$ 0.001 .

\begin{tabular}{|c|c|c|c|c|c|c|}
\hline \multirow[b]{3}{*}{ Graft combination } & \multicolumn{4}{|c|}{ Main stem length (cm/plant) } & \multicolumn{2}{|c|}{ Root length (m/plant) } \\
\hline & & & $\%$ & & & $\%$ \\
\hline & Control & Salt & Reduction & Control & Salt & Reduction \\
\hline Altinbas & $89.2 \mathrm{~A}$ & $40.3 \mathrm{c}$ & 54.8 & $32.7 \mathrm{D}$ & $41.2 \mathrm{c}$ & -26.0 \\
\hline Citirex & $70.0 \mathrm{D}$ & $29.4 \mathrm{~d}$ & 57.9 & $37.0 \mathrm{CD}$ & $28.3 \mathrm{~d}$ & 23.5 \\
\hline Nun 9075/ Citirex & $70.1 \mathrm{D}$ & $41.4 \mathrm{c}$ & 40.9 & 75.9 A & $57.1 \mathrm{~b}$ & 24.7 \\
\hline Nun 9075/ Altinbas & $74.1 \mathrm{CD}$ & $47.0 \mathrm{~b}$ & 36.6 & $52.6 \mathrm{~B}$ & $45.4 \mathrm{c}$ & 13.6 \\
\hline Kardosa/ Citirex & $76.3 \mathrm{BC}$ & $49.6 \mathrm{~b}$ & 34.9 & $48.2 \mathrm{~B}$ & $69.8 \mathrm{a}$ & -44.6 \\
\hline Kardosa/ Altinbas & $80.2 \mathrm{~B}$ & $55.1 \mathrm{a}$ & 31.3 & $41.5 \mathrm{C}$ & $55.8 \mathrm{~b}$ & -34.5 \\
\hline F Test & $\begin{array}{l}\text { Genotype } \\
* * *\end{array}$ & $\begin{array}{l}\text { Salt } \\
* * *\end{array}$ & $\begin{array}{l}\text { Gen.xSalt } \\
* * *\end{array}$ & $\begin{array}{l}\text { Genotype } \\
* * *\end{array}$ & $\begin{array}{l}\text { Salt } \\
\text { ns }\end{array}$ & $\begin{array}{l}\text { Gen.xSalt } \\
* * *\end{array}$ \\
\hline
\end{tabular}




\section{Conclusions}

Our study provides evidence that melon plants grafted onto different commercial Cucurbita maxima x C. moschata hybrid rootstocks and ungrafted plants performed differently under stress caused by saline conditions. The graft combination of Nun 9075/ Citirex was found more tolerant to salinity than ungrafted melon plants, and the other graft combinations used in regard to investigated parameters. Grafting onto salt tolerant Cucurbita maxima x C. moschata hybrid rootstocks can improve the growth performance of melon plants under salt stress. Future research is planned to study how suitable scion/ rootstock combinations under saline conditions affect fruit yield and quality parameters.

\section{References}

[1]: Navarro JM, Botella, MA and Martinez V (1999). Yield and fruit quality of me Ion plants grown under saline conditionsin relation to phosphate and calcium nutrition. Journal of Horticultural Science \& Biotechnology (1999) 74 (5) 573-578.

[2]: Edelstein M, Plaut Z, Ben-Hur M (2011). Sodium and chloride exclusion and retention by non-grafted and grafted melon and Cucurbita plants. - J. Exp. Bot. 62: 177-184.

[3]: FAO (2014). FAOSTAT Agricultural Database. http://www.fao.org/faostat/en/\#data/QC.

[4]: Flowers, TJ (1999). Salinisation and horticultural production. Sci. Hortic. 78, $1 \mathrm{e} 4$.

[5]: Kumar K, Kumar M, Kim SR, Ryu H, Cho YG (2013). Insights into genomics of salt stress response in rice. Rice $6,1 \mathrm{e} 15$.

[6]: Jacoby B (1994). Mechanisms involved in salt tolerance by plants. In: Pessarakli, M. (Ed), Handbook of plant and crop stress. Marcel Dekker, New York, pp, 97-123.

[7]: Marschner H (1995). Mineral nutrition of Higher Plants. Academic Press, London.

[8]: Franco JA, Esteban C, Rodriguez C (1993). Effects of salinity on various growth stages of muskmelon cv. Revigal. J. Hort. Sci. 68, 899e904.

[9]: Mendlinger S, Pasternak D (1992). Screening for salt tolerance in melons. Sci. Hortic. 27, 905e907.

[10]: Mavrogianopoulos GN, Spanakis J, Tsikalas P (1999). Effect of carbon dioxide enrichment and salinity on photosynthesis and yield in melon. Sci. Hort. 79, $51 \mathrm{e} 63$.

[11]: del Amor FM, Martinez V and Cerda A (1999). Salinity duration and concentration affect fruit yield and quality and growth and mineral composition of melon plants grown in perlite. HortScience 34: 1234-1237.

[12]: Gabrijel O, Davor R, Zed R, Marija R, Monika Z (2009). Cadmium accumulation by muskmelon under salt stress in contaminated organic soil. Science of the Total Environment, 407, 2175-2182.

[13]: Lee JM (1994). Cultivation of grafted vegetables I: current status, grafting methods and benefits. HortScience 29: 235-239.

[14]: Oda M (1995). New grafting method for fruit-bearing vegetables in Japan. Japan Agricultural Research Quarterly, 29: 187-194.

[15]: Pogonyi Á, PéK Z, Helyes L, Lugasi A (2005). Effect of grafting on the tomato's yield, quality and main fruit components in spring forcing. Acta Aliment. 34 453-462. 10.1556/aalim.34.2005.4.12.

[16. ]: Khah EM, Kakava E, Mavromatis A, Chachalis D, Goulas C (2006). Effect of grafting on growth and yield of tomato (Lycopersicon esculentum Mill.) in greenhouse and open-field. J. Appl. Hortic. 8 3-7.

[17]: Bletsos F, Thanassoulopoulos C, Roupakias D (2003). Effect of grafting on growth, yield and Verticillium wilt of egglant. HortScience 38:183-186.

[18]: Leonardi C and Romano D (2004). Recent issues on vegetable grafting. Acta Horticulturae, 631: 163-174.

[19]: Oka Y, Offenbach R, Pivonia S (2004). Pepper rootstock graft compatibility and response to Meloidogyne javanica and M. incognita. J. Nematol. 36:137-141.

[20]: García-Rodríguez MR, Chiquito-Almanza E, LoezaLara PD, Godoy-Hernández H, Villordo-Pineda E, PonsHernández JL, González-Chavira MM and AnayaLópez JL (2010). Production of ancho chili graft on criollo de morelos 334 for the control of Phytophthora capsici. Agrociencia 44, 701-709. 
[21]: Davis AR, Perkins-Veazie P, Hassell R, Levi A, King SR, Zhang X (2008a). Grafting effects on vegetable quality. HortScience 43 1670-1672.

[22]: Kumar P (2015). Grafting Affects Growth, Yield, Nutrient Uptake, and Partitioning Under Cadmium Stress in Tomato. HORTSCIENCE 50(11):1654-1661. 2015.

[23]: Rivero RM, Ruiz JM and Romero L (2003a). Can grafting in tomato plants strengthen resistance to thermal stress? J. Sci. Food Agric., 83, 1315-1319.

[24]: Riverio RM, Ruiz JM, Sanchez E and Romero L (2003b). Does grafting provide tomato plants an advantage against $\mathrm{H}_{2} \mathrm{O}_{2}$ production under conditions of thermal shock? Physiol. Plant. 117: 44-50.

[25]: Yetisir H and Uygur V (2008). Plant Growth and Mineral Element Content of Different Gourd Species and Watermelon under Salinity Stress. Turkish Journal of Agriculture and Forestry 33 (2009) 65-77.

[26]: Colla G, Rouphael Y, Leonardi C and Bie Z (2010). Role of grafting in vegetable crops grown under saline conditions. Scientia Horticulturae, 127:147-155.

[27]: Louws FJ, Rivard CL, Kubota C (2010). Grafting fruiting vegetables to manage soilborne pathogens, foliar pathogens, arthropods and weeds. Sci. Hortic. 127 127-146. 10.1016/j.scienta.2010.09.023.

[28]: Schwarz D, Rouphael Y, Colla G, Venema JH (2010). Grafting as a tool to improve tolerance of vegetables to abiotic stresses: thermal stress, water stress and organic pollutants. Sci. Hortic. 127 162-171. 10.1016/j.scienta.2010.09.016.

[29]: Lee JM, Oda M (2003). in Horticultural reviews, Grafting of herbaceous vegetable and ornamental crops, ed Janick J. (John Wiley \& Sons, New York, NY), Vol. 28, pp 61-124.

[30]: Yarsi G and Sari N (2006). Effects of grafted seedling on nutritional status of melon growing in greenhouse. Alatarim (in press).

[31]: Yarsi G, Sari N and Yetisir H (2012). Effect of different rootstocks on yield and quality of grafted melon plants. Acta Hort (ISHS) 936: 411-416.

[32]: Yetisir H and Sari N (2003). Effect of rootstock on plant growth, yield and quality of watermelon. Australian Journal of Experimental Agriculture 43: 1269-1274.

[33]: Zijlstra S, Groot SPC and Jansen J (2014). Genotypic variation of rootstocks for growth and production in cucumber; possibilities for improving the root system by plant breeding. Scientia Horticulturae Volume 56, Issue 3, January 1994, Pages 185-196

[34]: Blanco FF and Folegatti MV (2005). Estimation of leaf area under for greenhouse cucumber by linear measurements under salinity and grafting. Sci. Agric., 62(4): 305-309.

[35]: Edelstein M, Ben-Hur M, Cohen R, Burger Y, Ravina I (2005). Boron and salinity effects on grafted and nongrafted melon plants. - Plant Soil 269: 273-284.

[36]: Colla G, Rouphael Y, Cardarelli M, Rea E (2006). Effect of salinity on yield, fruit quality, leaf gas exchange, and mineral composition of grafted watermelon plants. HortScience, 41, 622-627.

[37]: Dasgan HY and Akhoundnejad Y (2012). Field performans of the some selected melon genotypes against to drought stress. Proceedings of the 9th National Vegetable Symposium. Konya-Turkey

[38]: Lee JM, Kubota C, Tsao SJ, Bie Z, Hoyos Echevarria P, Morra L and Oda M (2010). Current status of vegetable grafting: diffusion, grafting techniques, automation. Scientia Horticulturae, 127(2):93-105.

[39]: Yamac M (2017). Türkiye Su Kabağı (Lagenaria Siceraria) Genetik Kaynaklarndan Seçilmis Olan Su Kabağı Genotiplerinin Tųlu Koșullar Altında Karpuza Anaçlk. Potansiyellerinin Bekirlenmesi. Yüksek Lisans Tezi, Erciyes Üniversitesi, Seyrani Ziraat Fakültesi.

[40]: Öztekin GB (2009). Aşılı Domates Bitkilerinde Tuz Stresine Karşı Anaçlarn Etkisi. Yüksek Lisans Tezi, Ege Üniversitesi, Ziraat Fakültesi.

[41]: Chartzoulakis KS (2005). Salinity and olive: growth, salt tolerance, photosynthesis and yield. - Agron. Water Manage. 78: 108-121.

[42]: Stępień P, Kłobus G (2006). Water relations and photosynthesis in Cucumis sativus L. leaves under salt stress. Biol. Plant. 50: 610-616.

[43]: Zuccarini P (2008). Effects of silicon on photosynthesis, water relations and nutrient uptake of Phaseolus vulgaris under $\mathrm{NaCl}$ stress. - Biol. Plant. 52: 157-160.

[44]: He Y, Zhu Z, Yang J, Ni X, Zhu B (2009). Grafting increases the salt tolerance of tomato by improvement of photosynthesis and enbancement of antioxidant ensymes activity. Environ. Exp. Bot. 66, 270-278.

[45]: Ekbic E, Cagiran C, Korkmaz K, Kose MA and Aras V (2017). Assessment of watermelon accessions for salt tolerance using stress tolerance indices. Ciência e Agrotecnologia, 41(6):616-625, Nov/Dec. 2017

[46]: Kaya C, Tuna AL, Ashraf M, Altunlu H (2007). Improved salt tolerance of melon (Cucumis melo L.) by the addition of proline and potassium nitrate. Environ. Exp. Bot. 60, 397e403. 
[47]: Kaya C, Kirnak H and Higgs D (2001). Enhancement of growth and normal growth parameters by foliar application of potassium and phosphorus in tomato cultivars grown at high ( $\mathrm{NaCl}$ ) salinity. Journal of Plant Nutrition, 24 (2):357-367

[48]: Çelik Ö and Atak C (2012). The effect of salt stress on antioxidative ensymes and proline content of two Turkish tobacco varieties. Turkish Journal of Biology 36(3):339

[49]: Lei B, Huang Y, Xie JJ, Liu ZX, Zhen A, Fan ML, and Bie ZL (2014). Increased cucumber salt tolerance by grafting on pumpkin rootstock and after application of calcium. BIOLOGIA PLANTARUM 58 (1):179-184

[50]: Romero L, Belakbir A, Ragala L and Ruiz MJ (1997). Response of plant yield and leaf pigments to saline conditions: effectiveness of different rootstocks in melon plant (Cucumis melo L.). Soil Sci. Plant. Nutr. 43, 855862.

[51]: de Pascale $S$ and Barbieri G (1997). Effects of salinity and top removal on growth and yield of broadbean as a green vegetable. Sci. Hortic. 71: 147-165.

[52]: Yeo AR, Capron SJM, Flowers TJ (1985). The effect of salinity upon photosynthesis in rice (Oryza sativa L.): gas exchange by individual leaves relation to their salt content. - J. Exp. Bot. 36: 1240-1248.

[53]: Flexas, J., Bota, J., Loreto, F., Cornic, G., Sharkey, T.D. (2004). Diffusive and metabolic limitations to photosynthesis under drought and salinity in C3 plants. - Plant Biol. 6: 269-279.

[54]: Zhang, R.H., Li, J., Guo, S.R., Tezuka, T. (2009). Effects of exogenous putrescine on gas-exchange characteristics and chlorophyll fluorescence of NaCl-stressed cucumber seedlings. - Photosynth. Res. 100: 155-162.

[55]: Huang Y, Bie ZL, Liu ZX, Zhen A and Jiao XR (2011). Improving cucumber photosynthetic capacity under $\mathrm{NaCl}$ stress by grafting onto two salt-tolerant pumpkin rootstocks. Biologia Planatarum 55 (2): 285-290.

[56]: Rouphael Y, Cardarelli M, Rea E, and Colla G (2012). Improving melon and cucumber photosynthetic activity, mineral composition, and growth performance under salinity stress by grafting onto Cucurbita bybrid rootstocks. Photosynthetica 50 (2): 180-188, 2012.

[57]: Rengel Z (1992). The role of calcium in salt toxicity. Plant Cell Environment 15: 625-632.

[58]: Sivritepe HO, Sivritepe N, Eris A, and Turhan E (2005). The effects of $\mathrm{NaCl}$ pre-treatments on salt tolerance of melons grown under longterm salinity. Sci. Hortic. 106: 568-581.

[59]: van der Sanden PACM and Veen BW (1992). Effects of air bumidity and nutrient solution concentration on growth, water potential and stomatal conductance of cucumber seedlings. Sci. Hortic. 50: 173- 186.

[60]: Awang YB, Atherton JG and Taylor AJ (1993). Salinity effects of strawberry plants grown in rockwool I. Growth and leaf water relations. J. Hort. Sci. 68: 783-790.

[61]: Dasgan HY, Aktas H, Abak K and Cakmak I (2002). Determination of screening techniques to salinity tolerance in tomato and investigation of genotypes responses. Plant Sci. 163: 695-703.

[62]: Chartzoulakis $\mathrm{K}$ and Loupassaki MH (1997). Effects of $\mathrm{NaCl}$ salinity on germination, growth, gas exchange, and yield of greenhouse eggplant. Agric. Water Manage. 32: 214-225.

[63]: Chartzoulakis K and Klapaki G (2000). Response of two greenhouse pepper bybrids to $\mathrm{NaCl}$ salinity during different growth stages. Sci. Hortic. 86: 247-260.

[64]: Kovalev PA and Lisovskaya TP (1989). Pleiotropic effects of gene Bl and the formation of the inflorescence in tomato (Lycopersicon esculentum Mill.). Izvestiya Akademii Nauk Moldavskoi SSR. Biologicheskie i Khimicheskie Nauki, 3:69-71.

[65]: Kovalev PA (1990). Pleiotropic effects of the genes and YG6 and formation of the inflorescence in tomato. Izvestiya Akademii Nauk Moldavskoi SSR. Biologicheskie i Khimicheskie Nauki, 5: 34-36.

[66]: Ra SA, Yang JS, Ham IK, Mon CS, Woo IS, Roh TH, Hong YK (1995). Effect of remaining potato stems on yield of grafting plants between mini tomato and potato. RDA- J. Agric. Sci. Hortic., 37(2): 390-393.

[67. Ruiz JM, Romero L (1999). Nitrogen efficiency and metabolism in grafted melon plants. Sci. Hortic. 81, 113-123

[68]: Fernández-García N, Martínez V, Cerdá A, Carvajal M (2002). Water and nutrient uptake of grafted tomato plants grown under saline conditions. J. Plant Physiol. 2002;159:899-905.

[69]: Khah EM (2005). Effects of grafting on growth, performance and yield of aubergine in the field and greenhouse. J. Food Agric. Environ. 3, 92- 94.

[70]: Larcher W (1995) Physiological plant ecology:ecophysiology and stress physiology of functionalgroups. Springer-Verlag, Berlin, 540p.

[71]: Ashraf M, Arfan M and Ahmad A (2003). Salt tolerance in okra: Ion relations ve gas exchanges characteristics. J. of Plant Nutrition, 26(1), 63-79.

[72]: Dölarslan M, Gül E (2012). Toprak Bitki İlişkileri Açısından Tuz̨luluk. Türk Bilimsel Derlemeler Dergisi, 5(2): 56-59. 